\title{
Public social security burden of musculoskeletal diseases in Brasil- Descriptive study
}

Thaysa Simões Paixão Passalini ${ }^{1}$

Ricardo Fuller ${ }^{1}$

1. Faculdade de Medicina da Universidade de São Paulo

http://dx.doi.org/10.1590/1806-9282.64.04.339

\section{SUMMARY}

BACKGROUND: To present data on the social security burden of diseases of the musculoskeletal system and connective tissue (DSOTC) in Brasil in 2014, and evolution of these social security expenditures between 2009 and 2014.

METHOD: Compilation and analysis of data on the granting of disability pensions and sickness benefits in the year 2014, available on the official website of Social Security, classified according to ICD 10. It was evaluated the evolution between 2009 and 2014, using the $F$ test to compare the curves with the growth of the active age population (PIA).

RESULTS: Among the 22 disease groups classified according to ICD-10, the DSOTC group led benefits grants in 2014, with 19\% of the sickness benefits and $13.5 \%$ of the disability pensions. The main causes of sickness benefit and disability retirement were, respectively: dorsopathies (43.3\% and 41.2\%), soft tissue diseases (27.3\% and 19.7\%), osteoarthritis (7.6\% \% And 27.8\%) and chronic inflammatory arthropathies (2.8\% and 7.9\%). In the evolution of the number of sickness benefits granted between 2009 and 2014, both INSS and DSOTC totals showed an increasing tendency (35.9 and 35.3\%, respectively, with $p=0.000$ for both). As for disability retirement, there was a $5.9 \%$ increase in the INSS total $(p=0.039)$, while for the DSOTC there was a decrease of $7.6 \%(p=0.005)$.

CONCLUSIONS: These data point to a progressive increase in the granting of sickness pensions and disability benefits in the country, superior to the growth of the PIA, as well as a high participation of DSOTC in these benefits.

KEYWORDS: Social security. Musculoskeletal system. Insurance benefits. Salaries and fringe benefits.

\section{INTRODUCTION}

The Brazilian Social Security System, managed by the National Institute of Social Security (PS/INSS), is heading towards collapse given the huge gap between expenses and collection. ${ }^{1}$ Government strategies aimed at preventing or at least mitigating this negative balance have reached maximum attention and disclosure, constituting one of the main economic and social topics of discussion in the country'.

Partial data for June 2016 indicate a 12-month accumulated expenditure of BRL 438.16 billion, corresponding to $7.42 \%$ of GDP, with a negative social security balance of BRL 112.83 billion in the period. ${ }^{2}$
Between 2009 and 2014, for example, there was a 203\% increase in the number of sickness benefits and $27.8 \%$ in the number of disability pensions granted. Considering all types of INSS benefits, there was an increase of $76.7 \%$ in those five years. ${ }^{3}$ The fact that the growth of the economically active population in this period was only $10 \%$ is noteworthy. ${ }^{4}$ Also, benefits granted by the INSS in the same period had a cost increase of $508.8 \%{ }^{1}$, while inflation stood at $213.4 \%{ }^{5}$ These data are alarming, as they reveal a progressive and disproportionate increase in the indirect cost of health care system for the country.

Economic issues have been increasingly high-

DATE OF SUBMISSION: 22-Aug-2017

DATE OF ACCEPTANCE: 09-Sep-2017

CORRESPONDING AUTHOR: Thaysa Paixão

Rua Doutor Ovídio Pires de Campos, 255

Cerqueira César - São Paulo - SP - Brasil

05403-000 - Tel: (+55 11) 2661-0000

E-mail: thaysasimoes@gmail.com

fuller@uol.com.br 
lighting the health care system in the international scenario. This panorama is particularly relevant in relation to diseases of the musculoskeletal system and connective tissue (DSOTC, in the Portuguese abbreviation) due to their high prevalence. Reinforcing this assertion, the World Health Organization and the United Nations, in a joint action, have declared the period between 2000 and 2010 as the "Decade of Bone and Articulations". 6 The main objective of this initiative was to identify and assess the DSOTC economic burden in the world, calling on governments to prioritize this group of diseases in their political agendas.

Academic circles also address the impact of these diseases on health, social and economic issues using publications in scientific journals, ${ }^{7-10}$ but not yet with the magnitude that the problem demands.

Data on social security expenditures are available on the Brazilian Social Security Web Portal, ${ }^{2}$ but in a dispersed and fragmented way in several subdivisions. The objective of this study is to present this information filtered, grouped and tabulated in order to facilitate its registration and interpretation, as well as to evaluate its evolutionary behavior.

\section{METHODS}

The main source was the Historical Social Security Database, ${ }^{2}$ containing statistical yearbooks, available on the official social security web portal. Benefits were analyzed in the year 2014, whose data were the most recent available on the web portal at the time of the study. An analysis of the evolution of the granting of benefits between 2009 and 2014 was also made. Two types of benefits were considered: sickness benefits and disability pensions, since they are directly associated with health. The International Classification of Diseases [ICD; its full official name is International Statistical Classification of Diseases and Related Health Problems and it is maintained by the World Health Organization (WHO)] in its last version was used as a search filter (ICD 10), ${ }^{11}$ which has 22 chapters representing groups of diseases, maintaining the terminology of this one in the presentation of results. Six groups were considered for analysis: DSOTC encompassing ICDs MOO to M99, specific interest of the study, and, for comparison purposes, diseases of the circulatory system, neoplasia, diseases of the respiratory system, infections and mental disorders, as they are among the diseases of higher prevalence in our environment.

In the DSOTC group were considered individualized ICDs or, in some cases, grouped according to similar characteristics of the diseases in question. ${ }^{12}$, ${ }^{13}$ Based on this criterion, the following groups were defined: inflammatory spondyloarthritis, which included ICDs M02 (reactive arthropathies), M03 (postinfectious arthropathies), M07 (psoriatic and enteropathy arthropathies), M45 (ankylosing spondylitis) and M46 (other inflammatory spondylopathies); dorsopathies, consisting of the sequence of ICDs M40 to M54, except those of inflammatory spondylopathies (M45 and M46), which comprised the spondyloarthritis group; soft parts (ICDs M60 to M79); microcrystalline arthropathies (ICDs M10 and M11); osteoarthritis (ICDs M15 to M19) and rheumatoid arthritis (ICDs M05 and M06). ICDs M32 to M36, which include lupus, dermatopolymyositis, systemic sclerosis and other systemic connective tissue diseases were grouped under the denomination of diffuse connective tissue diseases. A group named "others" was established, encompassing diagnoses that in individual analysis were numerically minor, being grouped to facilitate the presentation of results. This group covers osteometabolic diseases (ICDs M80 to M90), juvenile idiopathic arthritis (ICDs M08 and M09), vasculitis (ICDs M30 to M31), infectious arthropathies (ICDs MOO and MO1), other arthropathies (ICDs M12 to M14), deformities of the musculoskeletal system (ICDS M20 and M25), chondropathies (ICDs M91 to M94) and miscellaneous (ICDs M95 to M99).

Assessment of the potential for permanent disability was established by the ratio of the number of permanent (retired) disabled persons to the total number of temporary and permanent disabled people (sick pay and disability retirement) for each ICD or set of ICDs, as defined above. With the aim of quantifying the evolution of the number of benefits granted between 2009 and 2014 in each disease or group of diseases evaluated, the simple linear regression analysis technique was used ${ }^{14}$ to obtain a predictive line of the number of cases per year and consequent analysis of the (growth or decline) trend of the volume of interest. Finally, evolutionary trends (or slopes of a straight line) of the benefits granted to sickness or group of sicknesses with the evolutionary trend of the working-age population (WAP $)^{15}$ in the same period in order to be able to propose specif- 
ic research on a certain disease or group of diseases with out-of-expected behavior for the population as a whole. The WAP was chosen because it contained the individuals exposed to occupational outcomes addressed (population between 15 and 64 years of age). ${ }^{4}$ This comparative analysis was performed by an F-test between the slopes of the WAP straight lines and each disease or group of diseases. The year 2009 was adopted based on $100^{16}$ so that the differences observed would not be due to discrepancies among the values and also so that trends (or inclinations) could be identified.

\section{RESULTS}

Considering the benefits accruing, in 2014, 2,328,151 sickness benefits were granted, which accounted for $43.6 \%$ of all benefits (including social security, welfare and accident benefits) from the National Institute of Social Security. In that year, 189,651 new disability pensions were registered or $3.5 \%$ of the total benefits.

Analyzing ICD 10 main groups of diseases, the most represented in the benefits granted in 2014 was that of DSOTC, responsible for $19.0 \%$ of the total sickness benefits. By comparison, mental disorders, corresponding to $9.0 \%$, diseases of the circulatory system, $7.4 \%$ and neoplasms, $6.9 \%$, were next. In terms of disability pensions, DSOTC accounted for $13.5 \%$ of total benefits granted in 2014, followed by diseases of the circulatory system (13.4\%), respiratory diseases $(12.6 \%)$, neoplasias $(7.6 \% \%)$ and mental disorders (6.3\%).
When the search parameter in the Social Security web portal was the individualized ICD, the most prevalent benefits in number were: back pain - M54 (108852), leg fractures - S82 (87591), hand and wrist fractures - S62 (71623) and disorders of intervertebral discs - M51 (64018). It is important to note that the website recorded 90,242 cases with "ignored" diagnosis (written as 999 in the ICD search). Using the same search system for disability pensions, back pain M54 continued as the most prevalent ICD, with 4,566 grants, followed by disorders of intervertebral discs - M51 $(4,337)$, stroke - I64 $(3,686)$ and knee arthrosis - M17 (3,602). For this type of benefit, the website records 72,677 grants with "ignored" ICD.

Considering only the group of diseases of the musculoskeletal system and connective tissue, dorsopathies remained the main causes for granting sickness benefits, with $43.3 \%$, followed by soft tissue diseases (27.3\%), osteoarthritis (7.6\%) and chronic inflammatory arthropathies (2.8\%) (Figure 1). Also within the DSOTC, the dorsopathies group accounted for $41.2 \%$ of disability pensions (Figure 1). On the other hand, osteoarthritis was the second most common, with $27.8 \%$ of the pensions, followed by soft tissue diseases $(19.7 \%)$ and chronic inflammatory arthropathies $(7.9 \%$, especially rheumatoid arthritis, with 4.5\%) (Figure 1).

Granting disability retirement in relation to the sickness benefit

The ratio of the number of invalidity pensioners to the sum of the number of sickness benefit recipients and the number of disability pensioners in 2014 was

FIGURE 1. SOCIAL SECURITY DISABILITY INSURANCE X STATUTORY SICK PAY

Social security disability insurance

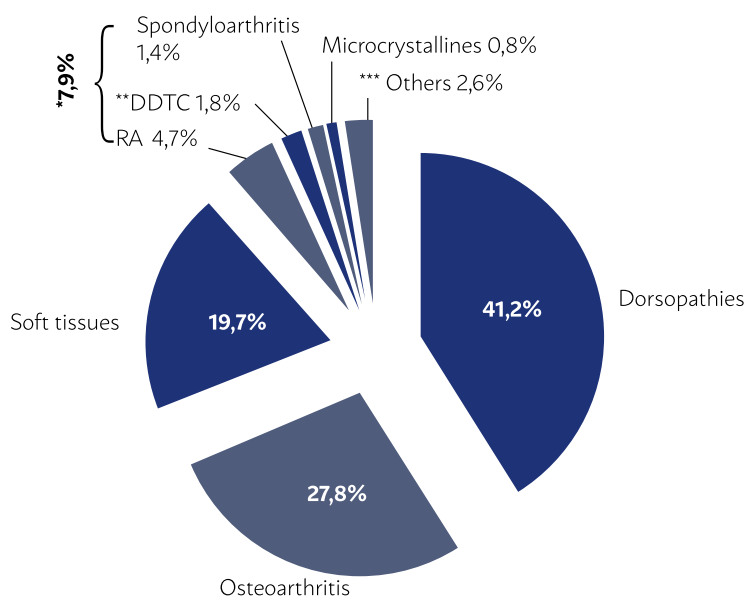

Statutory sick pay

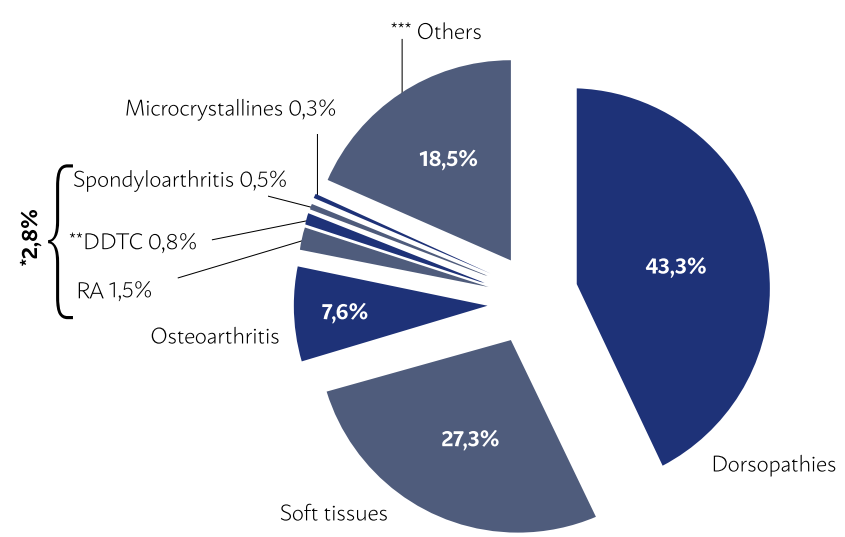


7.53\% for the total benefits granted by the INSS. For the DSOTC, the ratio was 5.52\%. The ratio for other large groups was: diseases of the circulatory system, 12.83\%; neoplasias, $8.28 \%$; diseases of the respiratory system, $91.69 \%$; infections, $6.38 \%$, and mental disorders, $5.42 \%$. As for most of the diseases of the DSOTC group, the ratio was higher than that observed in the INSS total: systemic sclerosis, $25.05 \%$; osteoarthritis, 17.55\%; rheumatoid arthritis, 15.28\%; myopathies, $15.12 \%$; vasculitis, $14.40 \%$; spondyloarthritis, 13.16\%; juvenile idiopathic arthritis, 7.93\%; osteoporosis, $11.81 \%$, and lupus, $10.03 \%$. Exceptions were the dorsopathies and soft tissues subgroups, which present a much lower ratio $(5.12 \%$ and $2.84 \%$, respectively), but together represent approximately $70 \%$ of the total benefits for musculoskeletal and connective tissue and their values end up determining the values of the average of $5.52 \%$ of the DSOTC group.

Evolution of benefits between 2009 and 2014 For sickness benefits, both INSS and DSOTC groups showed a growing trend between 2009 and 2014 (35.9\% and 35.3\%, respectively, $p=0.000$ for both) (Figure 2). These rates mean an average increase of 132,199 cases of sickness benefits per year in the total INSS and 22,429 more cases per year for DSOTC. This increase was higher than the growth of the working-age population (WAP) in the period, which was $6.5 \%(p=0.000$ for total INSS benefits and for DSOTC) (Figure 2). Separately considering the subgroups of diseases within DSOTC, soft tissue rheumatism, spondyloarthritis and osteoarthritis presented an increasing trend, and that of microcrystalline arthropathies, a decreasing trend (Table 1). All these trends remained significant when compared to WAP growth in the period (Table 1). In the case of dorsopathies and rheumatoid arthritis, despite a numerical increase, variation was not significant.

Disability pensions as a whole showed an increase of $5.9 \%$ in the period or an average of 2,352 more cases per year $(p=0.039$ for trend), while for the DSOTC there was a decreasing trend of $7.6 \%$ with an average of 394 fewer cases per year $(p=0.005)$ (Table 1). Subgroups of spondyloarthritis, rheumatoid arthritis, dorsopathies and osteoarthritis showed a significant reduction trend, whereas connective tissue diseases and
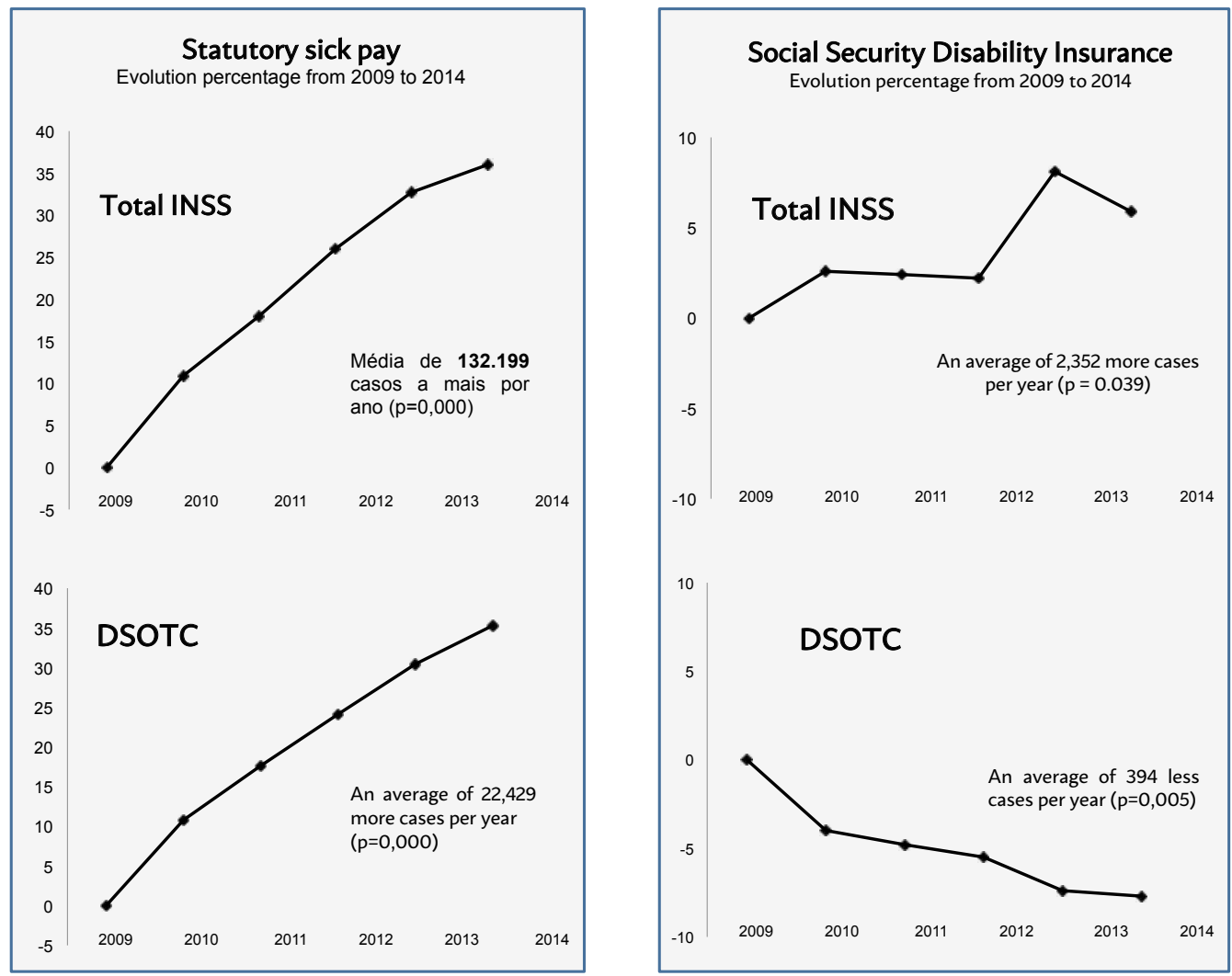
microcrystalline arthropathies showed numerical reduction without configuring trend. On the other hand, soft tissue diseases showed an increasing trend (Table 1). Once again all these trends remained significant when compared to WAP growth in the period (Table 1).

\section{DISCUSSION}

Evaluation of public health care system data in Brasil shows that the DSOTC were the main responsible ones for social security benefits in the health care sector in the year of 2014 analyzed.

By comparison, in Italy, a country with a public pension system similar to the Brazilian one, that is, where social security costs are borne by the government, the DSOTC, although quite expressive, corresponded to the third cause of short-term absenteeism and only in the tenth place in the generation of permanent benefits (similar, respectively, to sickness benefits and to disability retirement in Brasil). ${ }^{9}$

Obviously, there are limitations to the interpretation of the data inherent to the descriptive nature of this study but it is possible to formulate hypotheses for the prevalence of DSOTC in social security claims. Increase in their impact could basically be due to the phenomena of demographic transition (mortality and birth rate, culminating in an aging population, a range in which the prevalence of degenerative diseases of the locomotor system is greater) and epidemiological transition from morbidity and mortality in emerging countries, from infectious to chronic-degenerative diseases).

Regarding evolutionary behavior, INSS's sickness benefit and disability pension as a whole presented growth higher than that verified in the working-age population (WAP) between 2009 and 2014. Choice of

\section{TABLE 1}

\section{STATUTORY SICK PAY}

\begin{tabular}{|c|c|c|c|c|}
\hline Disease & Variation & Tendency & $P$ & Comparison to PIA \\
\hline Total INSS & $+35,9 \%$ & $\uparrow$ & 0,000 & \\
\hline DSOTC & $+35,3 \%$ & $\uparrow$ & 0,000 & 0,000 \\
\hline DDTC & $+45,0 \%$ & $\uparrow$ & 0,001 & 0,000 \\
\hline Soft tissues & $+42,9 \%$ & $\uparrow$ & 0,000 & 0,000 \\
\hline Dorsopathies & $+32,3 \%$ & - & 0,740 & - \\
\hline Spondylarthritis & $+34,9 \%$ & $\uparrow$ & 0,046 & 0,049 \\
\hline Rheumatoid arthritis & $+18,2 \%$ & - & 0,197 & - \\
\hline Osteoarthritis & $+13,2 \%$ & $\uparrow$ & 0,001 & 0,001 \\
\hline Microcrystallines & $-7,7 \%$ & $\downarrow$ & 0,022 & 0,000 \\
\hline
\end{tabular}

SOCIAL SECURITY DISABILITY INSURANCE

\begin{tabular}{l|l|l|l|l}
\hline Disease & Variation & Tendency & $P$ & Comparison to PIA \\
\hline Total INSS & $+5,9 \%$ & $\uparrow$ & 0,039 & \\
\hline DSOTC & $-7,6 \%$ & $\downarrow$ & 0,005 & 0,001 \\
\hline Spondylarthritis & $-54,3 \%$ & $\downarrow$ & 0,021 & 0,003 \\
\hline Rheumatoid arthritis & $-16,7 \%$ & $\downarrow$ & 0,003 & 0,000 \\
\hline Dorsopathies & $-13,3 \%$ & $\downarrow$ & 0,001 & 0,000 \\
\hline DDTC & $-13,0 \%$ & - & 0,439 & - \\
\hline Microcrystallines & $-8,4 \%$ & - & 0,407 & - \\
\hline Osteoarthritis & $-7,3 \%$ & $\downarrow$ & 0,003 & 0,000 \\
\hline Soft tissues & $+21,8 \%$ & $\uparrow$ & 0,008 & 0,015 \\
\hline
\end{tabular}


this indicator as a reference is due to the fact that it covers individuals exposed to occupational outcomes addressed (population between 15 and 64 years of age). ${ }^{4}$ Also for comparison, Italy has shown decrease in granting short-term benefits in a recent period. ${ }^{9}$ In the field of hypotheses, it can be speculated that in Brasil there might be pressure generated by precariousness and low labor remuneration and rising unemployment associated with some culture of seeing the State as a provider (the financing of social security in Brasil follows the arrangement of partition and not capitalization). ${ }^{17}$ These propositions could lead individuals to seek social security benefits more often.

Interestingly, in the DSOTC group, while the sickness benefit has shown an upward trend, following the profile of INSS benefits, disability pensions have decreased. Again explanations for the phenomenon are in the field of hypotheses: greater rigor in expert procedures, greater control of these diseases, with lower ratio of patients evolving to permanent disability. Another possibility would lie in the heterogeneous nature of DSOTC. This last aspect has been explored in the evaluation of the percentage ratio between disability pensions and the sum of pensions plus sickness benefits. From this perspective, it has been found that many diseases in the DSOTC group, such as connective tissue diseases and vasculitis, had a higher ratio than the INSS mean, signaling a greater incapacitating potential, although they are less prevalent. On the other hand, dorsopathies and soft tissue rheumatism, although less disabling, drag down the evolutionary trend of the group over time because they are much more frequent.

Osteoarthritis is the single most commonly diagnosed illness-related disability, accounting for more than a quarter of disability pensions. This profile may be due to its high prevalence in the population (in Brasil, $4.1 \%$ at 36 years and $15.8 \%$ at 55 years), ${ }^{18}$ leading to an expressive number of patients for permanent incapacitation. As for lupus, although much more severe, it can occur with periods without clinical activity in response to treatment, leading to a relatively lower number of individuals for permanent disability. Dorsopathies and soft tissue rheumatisms constitute a group with such a large and heterogeneous number of diseases that they deserve careful interpretation, based on more data than those presented here.

Tabulation and availability of data by the INSS represent an important instrument for better un- derstanding the socioeconomic dimension of public health care. However, there are still gaps to be filled. There was, for example, an unexpected and high occurrence of "neglected" ICD, which may have influenced the relative distribution of benefits across the different disease groups. In addition, there is no information on the time spent away in cases of sickness benefits or the individual cost of each benefit so that the exact financial size of the disease groups could be obtained. In this way, it is not possible to analyze, for example, which categories of diseases lead to a longer period of remoteness and are more costly for the system. Regarding the temporal aspect, the INSS only provides the complete, tabulated and organized data of a given year long after they were generated, limiting this study to the data obtained until 2014 (available at the time of this study). Finally, it must be taken into account that the descriptive nature of the data does not allow their more in-depth and critical interpretation.

It is important to note that, although Brasil adopt a basically public pension system, there are other financing patterns. Thus, based on information obtained from NATLEX, ${ }^{19}$ a global database with information on social security, labor and human rights, maintained by the International Labor Organization, some authors ${ }^{20}$ have compared the social security system of 22 countries with regard to short-term absenteeism (paid sick day - about five days) and in the long term (sick leave - 50 or more days). Australia, Norway, New Zealand, the Netherlands, Switzerland and the United Kingdom leave the payment of both benefits to the employer. Nor does the United States impose such an obligation. Austria, Belgium, Canada, Finland, Germany, Iceland, Luxembourg, Japan, Sweden and Spain offer social security only for longterm cases (most of them help the employer to pay the long term one). Only Denmark, France, Ireland and Italy offer state social security for both departures, similar to the Brazilian system.

In conclusion, the data presented in this study point to a progressive and higher increase in the evolution of the working-age population (WAP) in granting sickness and disability benefits in Brasil, as well as a high participation of diseases of the musculoskeletal system and connective tissue. It is plausible that this situation can be modified with policies that improve the resolution and comprehensiveness of medical care to the population, as well as improving mechanisms for evaluating and granting benefits to recipients. 


\section{RESUMO}

OBJETIVOS: Apresentar dados sobre o ônus previdenciário das doenças do sistema osteomuscular e tecido conjuntivo (DSOTC) no Brasil no ano de 2014, e sua evolução entre 2009 e 2014.

MÉTODO: Compilação e análise de dados sobre a concessão de aposentadorias por invalidez e auxílios-doença no ano de 2014 disponíveis no portal oficial da Previdência Social, classificados segundo o CID 10. Avaliação da evolução entre 2009 e 2014, utilizando-se o teste F para comparar as curvas com o crescimento da população em idade ativa (PIA).

RESULTADOS: Entre 22 grupos de doenças classificados de acordo com o CID 10, o das DSOTC liderou as concessões de benefícios em 2014, com 19\% dos auxílios-doença e 13,5\% das aposentadorias por invalidez. As principais causas de concessão de auxílio-doença e aposentadoria por invalidez foram, respectivamente: dorsopatias (43,3\% e 41,2\%), doenças de partes moles (27,3\% e 19,7\%), osteoartrite (7,6\% e 27,8\%) e artropatias inflamatórias crônicas (2,8\% e 7,9\%). Na evolução do número de auxílios-doença concedidos entre 2009 e 2014, tanto o total do INSS quanto o do grupo DSOTC apresentaram tendência crescente (35,9 e 35,3\%, respectivamente, com $p=0,000$ para ambos). Já para aposentadoria por invalidez, houve aumento de 5,9\% no total do INSS ( $p=0,039)$, enquanto que para as DSOTC houve um decréscimo de 7,6\% ( $p=0,005)$.

CONCLUSÕES: Verificou-se uma elevação progressiva na concessão de auxílio-doença e aposentadoria por invalidez no País, superior ao aumento da população em idade ativa. As DSOTC foram o grupo com maior participação relativa nesses benefícios.

PALAVRAS-CHAVE: Previdência social. Sistema musculoesquelético. Benefícios do seguro. Salários e benefícios.

\section{REFERENCES}

1. Brasil, Ministério da Fazenda. Portal da Previdência Social. Reforma da Previdência. [cited 2017 |un 12] Available from: <http://www.previdencia.gov.br/reforma/>

2. Brasil, Ministério da Fazenda. Portal da Previdência Social. Boletim estatístico anual - [cited 2016 Oct 16] Available from: <http://trabalho. gov.br/dados-abertos/dados-da-previdencia/previdencia-social-e-inss/anuario-estatistico-da-previdencia-social-aeps>

3. Brasil, Ministério da Fazenda. Portal da Previdência Social - Dados abertos- Previdência Social e INSS. [cited 2016 Oct 2] Available from: <http:// www.previdencia.gov.br/dados-abertos/dados-abertos-previdencia-social/>

4. Instituto Brasileiro de Geografia e Estatística. Popclock: projeção de população. [cited 2016 Sept 28] Available from: <http://www.ibge.gov.br/ apps/populacao/projecao/notatecnica.html>

5. Índices de Inflação - IGPM. [cited 2016 Sept 28] Available from: <http:// fundos.economia.uol.com.br/uol/calculadora-indices-inflacao>

6. Wolf AD. The bone and joint decade 2000-2010. Ann Rheum Dis. 2000;59(2):81-2.

7. Laires P, Gouveia M, Branco J. O impacto económico das doenças reumáticas. Observatório Nacional das doenças reumáticas de Portugal. [cited 2016 Sept 28] Available from: <http://www.spreumatologia.pt/ observatorio-de-doenças-reumaticas>

8. Bhattachaya A, Leigh JP. Musculoskeletal disorder costs and medical claim filing in the US retail trade sector. Ind Health. 2014;49(4):517-22.

9. Russo S, Mariani TT, Migliorini R, Marcellusi A, Mennini FS. The pension costs of musculoskeletal diseases. Estimation of the economic burden borne by the Italian Social Security System. Value Health. 2016;17(7):A377-8
10. Klak A, Raciborski F, Samel-Kowalik P. Social implications of rheumatic diseases. Reumatologia. 2016;54(2):73-8.

11. International Statistical Classification of Diseases and Related Health Problems. 10 ${ }^{\text {th }}$ Revision. [cited 2016 Sept 28] Available from: <http:// apps.who.int/classifications/icd10/browse/2010/en>

12. Hochberg MC, Silman A, Smolen IS, Weinblatt ME, Weisman MH. Rheumatology. $6^{\text {th }}$ ed. Philadelphia: Elsevier; 2014.

13. Firesteins G, Budd R, Gabriel SE, Mclnnes IB, O'Dell J. Kelley's textbook of rheumatology $9^{\text {th }}$ ed. Philadelphia: Saunders; 2013

14. Kutner MH, Nachtsheim C), Neter J, Li W. Applied linear statistical models. $4^{\text {th }}$ ed. Boston: McGraw-Hill; 1996.

15. Instituto Brasileiro de Geografia e Estatística. Portal SIDRA/IBGE. [cited 2016 Oct 24] Available from: <https://sidra.ibge.gov.br/pesquisa/pme/ quadros/total-das-areas/fevereiro-2016>.

16. Guedes $T A$, Ivanqui $L$, Martins $A B$. Comparando equações de regressão em dados de saúde. Acta Scientiarum Technol. 2008;23:1531-5.

17. Amaro MN, Meneguim FB. A Previdência Social e a sustentação das finanças públicas: a atuação do Poder Legislativo. Rev Informação Legislativa. 2010;47(187):91-107.

18. Senna ER, Barros AL, Silva EO, Costa IF, Pereira LV, Ciconelli RM, et al. Prevalence of rheumatic diseases in Brazil: a study using the COPCORD approach. J Rheumatol. 2004;31(3):594-7.

19. International Labour Organization. NATLEX- Database of national labour, social security and related human rights legislation. [cited $2017 \mathrm{Apr} 27$ ] Available from: <http://www.lo.org/dyn/natlex/natlex4.byCountry?p_ lang=en>

20. Heymann J, Jin Rho HJ, Schmitt J, Earle A. Ensuring a healthy and productive workforce: comparing the generosity of paid sick day and sick leave policies in 22 countries. Int J Health Serv. 2010;40(1):1-22. 